\section{En politik med rækkevidde: Samarbejdspolitikken og de danske kz-fanger}

Afmuseumsleder, Ph.d. Henrik Skov Kristensen

\section{Det danske særtilfælde}

T ndledningsvis vil jeg gøre et par afklarende bemærkninger til titlen: Først og

- fremmest forudsætter jeg accept af den præmis, at samarbejdspolitikken, eller forhandlingspolitikken om man vil, fortsatte efter regeringens tilbagetræden den 29. august 1943 og frem til maj 1945, blot under andre former.

Efter den 29. august 1943 insisterede Tyskland stadigvæk på, at Danmark var et neutralt, suverænt land, som man ikke var i krig med. De dansk-tyske relationer blev fortsat ordnet mellem de to landes udenrigsministerier, og Danmark forblev helt frem til maj 45 det tyske udenrigsministeriums ressort - selv om både værnemagten og SS unægtelig i stigende grad vandt indflydelse.

Fra dansk side opretholdtes også fiktionen om et uafhængigt og suverænt Danmark: Det såkaldte Departementschefstyre, som afløste regeringen efter den 29. august 1943, holdt således aldrig op med overfor tyskerne at referere til "løfterne fra den 9. april 1940", da den danske regering (under protest) til gengæld for et tysk løfte om dansk suverænitet og territorial integritet gik ind på en tysk fredsbesættelse af Danmark. Den norske regering fik som bekendt det samme tilbud den 9. april 1940, men tog ikke mod det, ganske som den hollandske regering heller ikke gjorde det måneden efter. Begge lande kom derved i krig med Tyskland, som under den påfølgende besættelse etablerede tyske forvaltninger i dem begge. Både Norge og Holland blev såkaldte Reichskommissariater.

Den forhandlingstradition, der med den tyske fredsbesættelse af Danmark den 9. april 1940 blev etableret mellem besættelsesmagten og de danske myndigheder, rummede en stærk inerti, som lige frem til maj 45 formede den tyske besættelsespolitik i Danmark og sikrede landet særstatus i det tysk-besatte Europa. Selv for danske statsborgere i fjerne tyske kz-lejre greb de helt særegne besættelsespolitiske forhold i Danmark afgørende ind. Derfor skal det også forstås helt bogstaveligt, når jeg i titlen karakteriserer samarbejdspolitikken som "en politik med rækkevidde"!

Den sidste kommentar, jeg vil gøre til min titel er, at jeg til "danske kzfanger" ogsá i en vis forstand vil henregne fangerne i den danske Frøslevlejr. Dels indgik Frøslevlejren helt centralt i deportationsproblematikken, dels var Frøslevlejren i princippet en koncentrationslejr, om end ikke i formel forstand.

\section{Deportationer fra Danmark og den tyske repressaliepolitik \\ $\mathrm{N}$ æsten 6.100 danskere blev depor- teret til tugthus eller koncentrati- onslejr i Tyskland.} jende grad skete uden lov og dom - i hvert fald for så vidt angik deportationerne til $\mathrm{Kz}$ lejr-blev en hovedanstødssten i det dansktyske forhold. Først og fremmest fordi de greb centralt ind i selve besættelsesordningen i Danmark. Fra dansk side opfattede man nemlig deportationerne som et indgreb i den danske suverænitet og som et brud på Folkeretten. 
Efter den 29. august $1943 \mathrm{blev}$ deportationerne et tilbagevendende temaja, efterhånden et altoverskyggende sådant i det dansk-tyske forhold. Og i deportationernes kølvand fulgte konfrontationer mellem befolkning og besættelsesmagt, f.eks. i form af omfattende strejker.

For tyskerne indgik deportationerne først $\mathrm{og}$ fremmest som ét instrument blandt flere $\mathrm{i}$ arsenalet af repressalier, som man tillagde generalpræventiv virkning i bekæmpelsen af modstanden i det tyskbesatte Europa.

Anvendelsen af deportationer i Danmark vekslede over tid og var bestemt dels af besættelsesmyndighedernes holdning, dels af den generelle tyske repressaliepolitik i de besatte lande. I det spil havde den generelle politik, som blev fastlagt $\mathrm{i}$ førerhovedkvarteret, forrang.

I december 1941 udstedte Hitler den såkaldte Nacht-und Nebelerlass - en forordning, hvorefter modstandere i de besatte vesteuropæiske lande, herunder Norge, som et alternativ til en krigsretsdødsdom i hjemlandet kunne deporteres hemmeligt til Tyskland, hvor de skulle "forsvinde". De deporterede blev afskåret fra enhver forbindelse til hjemlandet.

Nacht- und Nebelerlass gjaldt udtrykkeligt ikke for Danmark på grund af landets specielle besættelsespolitiske status.

Frem til august 1943 var kun omkring 10 danske deporteret til strafafsoning i Tyskland, dvs. indsat i fængsel eller tugthus. Et så lavt antal deporterede på det relativt sene tidspunkt af krigen var enestående i europæisk sammenhæng - og skyldtes samarbejdspolitikken.

Men som sabotagen tog til, stillede Værnemagten i Danmark krav om hårdere repressalier. I begyndelsen af august 43 meddelte tyskerne, at sabotører, der ved tysk krigsret var idømt straffe på over 8 år, automatisk skulle afsone i Tyskland. På grund af danske protester opgav tyskerne imidlertid tanken.

Den 29. august 1943 blev skelsættende, hvad angik deportationerne. $\mathrm{Nu}$ blev straffene for sabotage skærpet, og stort set alle domfældte blev sendt til afsoning i Tyskland.

Deportationen af ca. 480 jøder og 150 kommunister i oktober 1943 til henholdsvis ghettoen Theresienstadt i Böhmen og koncentrationslejren Stutthof $\mathrm{i}$ det daværende Danzig var de første massedeportationer fra Danmark. Og som det hed i de danske myndigheders efterfølgende protestnote til besættelsesmagten, så skete det, uden at de deporterede havde gjort sig skyldige i noget strafbart forhold.

I bekæmpelsen af den tiltagende sabotage i efteråret 1943 gik både den rigsbefuldmægtigede Werner Best og chefen for det tyske politi i Danmark SS- Obergruppenführer Günther Pancke ind for traditionelle politimæssige metoder, dvs. efterforskning, anholdelse og pådømmelse ved tysk krigsret. Værnemagtens overkommando, OKW, derimod, advokerede for såkaldte "soningsaktioner", altså repressalier mod civilbefolkningen, ganske som det blev praktiseret $\mathrm{i}$ andre besatte lande.

I november-december 1943

gjorde både Hitler og Himmler det klart for besættelsesmyndighederne i Danmark, at soningsaktioner også skulle bringes i anvendelse i Danmark. Krigsretsjurisdiktionen, derimod, skulle nedbringes til et minimum. Det er nærliggende at se deportationerne i november-december 1943 og januar 1944 af $\mathrm{i}$ alt 168 danskere til koncentrationslejren Sachsenhausen og kvindelejren Ravensbrück i lyset af denne nye kurs. Ingen af de deporterede havde været stillet for retten. 


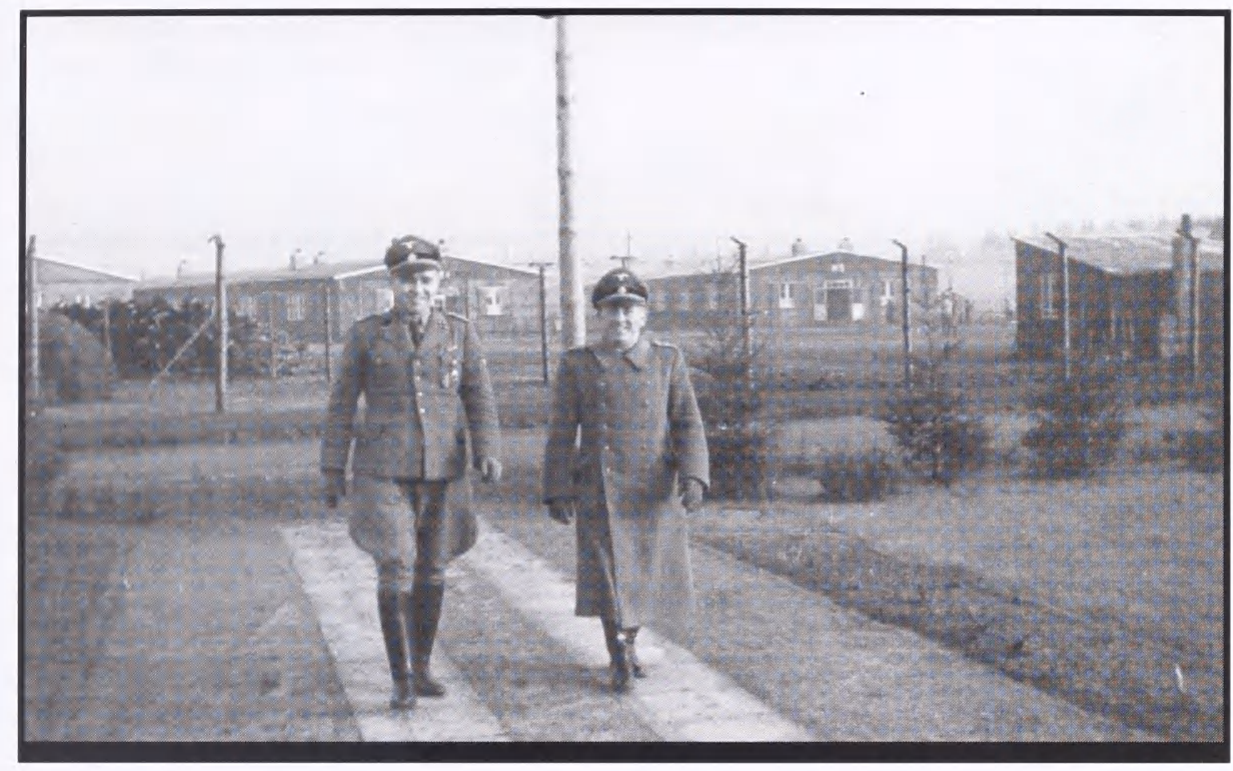

Kommandantskifte i Froslevlejren, december 1944. SS-Sturmbannführer Hillgärtner (t.v) afloses af SSHauptsturmführer Schriever (t.h.) som lejrkommandant. Som Polizeigefangenenlager sorterede Froslevlejren under Det tyske Sikkerhedspoliti, hvis chef i Danmark, SS-Standartenfiihrer und Oberst der Polizei Otto Bovensiepen, lagde retningslinierne for driften af lejren. Foto: Froslevlejrens Museum.

De danske myndigheder protesterede heftigt under henvisning til Folkeretten og den ubetingede ret, enhver dansk statsborger havde til at opholde sig på dansk grund. Og i den protestnote, som direktøren i udenrigsministeriet Nils Svenningsen afleverede til Werner Best, krævede man yderligere de deporterede bragt hjem til Danmark.

\section{Tyske politifangelejre i Danmark}

tillet over for rygterne om en foreståS ende massedeportation intervenerede Nils Svennigsen den 1. marts 1944 overfor Best, der som begrundelse for deportationen angav mangel på fængselsplads i Danmark. På den baggrund gentog Svenningsen et forslag fra januar 1944 om, at der blev oprettet en lejr på dansk grund, hvor man kunne internere danske statsborgere - for at forhindre, at de blev deporteret til Tyskland.

Et lignende forslag om en interneringslejr på dansk grund havde departementscheferne udviklet allerede i forbindelse med den forestående aktion mod de danske jøder i oktober 43. Ved den lejlighed havde Best-lykkeligvis tør man tilføje - skudt forslaget ned. Det samme havde han gjort i januar 1944, da Svenningsen også var inde på tanken om en lejr i Danmark. Men nu vandt forslaget altså genklang hos Best, og også hos chefen for det tyske Sikkerhedspoliti i Danmark, SS-Standartenführer Otto Bovensiepen.

En lejr med tyskerne som bygherre blev opført ved Frøslev plantage nær Padborg ved den dansk-tyske grænse. De danske myndigheder, som skulle betale for 
både opførelsen og driften af lejren, forsøgte at opnå tilsagn om, at de danskere, som allerede var blevet deporteret til Tyskland, skulle føres tilbage til den nyopførte lejr. Det så Best positivt på, dog med undtagelse af jøderne og visse af de ledende kommunister.

Den 13. august 1944 ankom de første 750 fanger til Frøslevlejren fra Horserødlejren på Sjælland, og det danske ønske om en tilbageførsel af deporterede til Frøslevlejren blev aldrig indfriet.

Frøslevlejren bliver almindeligvis betragtet som et helt specifikt dansk fænomen, hvilket imidlertid er en sandhed med modifikationer. Frøslevlejren, og i øvrigt også Horserødlejren i dens sidste fase, var i tysk politi-terminologi en såkaldt Polizeigefangenenlager. Tilsvarende lejre - også benævnt Polizeihäftlingslager eller Polizeihaftlager uden at det synes at have gjort nogen substantiel forskel - fandtes ud over det tysk-besatte Europa, f.eks. Grini-lejren i Norge, som var en Polizeihäftlingslager, eller Falstadlejren ligeledes i Norge, der ved etableringen benævntes SS-Strafgefangenenlager, men som i al bevaret skriftlig tysk kildemateriale i øvrigt betegnes som en Polizeihäftlingslager. Fælles for disse lejre var, at de rummede Det tyske Sikkerhedspolitis fanger, som blev interneret uden lov og dom. Således var det chefen for Det tyske Sikkerhedspoliti i Danmark, Otto Bovensiepen, som lagde retningslinierne for driften af Frøslevlejren. Lejrens kommandantskab bestod af SS-personel tilknyttet Sikkerhedspolitiet, medens det var personel fra det tyske Ordnungspolizei i Danmark, som varetog den indre lejrledelse, først og fremmest opsynet med fangerne.

Hvad der imidlertid synes at have gjort Frøslevlejren (og i øvrigt også Horserødlejren i dens sidste fase) helt speciel i europæisk sammenhæng, var den såkaldte
"Danske Forvaltning": Under forhandlingerne om Frøslevlejrens etablering lykkedes det departementschefstyret at få tyskerne til at acceptere, at fængselspersonellet i Den danske Forvaltning i Horserød rykkede med, da Horserødlejren så at sige blev omplantet til Sønderjylland den 13. august 1944. Den danske Forvaltning, som havde ansvaret for fangernes forplejning og visse andre forsyninger, fik til huse lige uden for det egentlige lejrområde, bl.a. fordi forvaltningen ikke selv ønskede at have nogen eksekutiv beføjelse i forhold til lejrens drift og opsynet med fangerne. Inde i selve lejren var Den Danske Forvaltnings hovedbastion lejrkøkkenet, og man tør fastslå, at Departementschefstyrets forlængede arm i Frøslevlejren sørgede for, at fangerne fik en både rigelig og nærende kost.

Lægger man dertil, at brutalitet, ydmygelser, vold og drab stort set ikke forekom i Frøslevlejren, retfærdiggør det betegnelsen "verdens mærkeligste kz-lejr", som tidligere Frøslevfanger har karakteriseret lejren.

Men strukturelt og principielt var Frøslevlejen ikke desto mindre en slags kz-lejr - ganske som Grini og Falstad i Norge var det, og alle havde de samme kommandolinier tilbage til Reichsicherheitshauptamt i Berlin. Forskellen på de norske og de danske lejre bestod hovedsageligt i de to landes væsensforskellige besættelsespolitiske forhold, som i høj grad fandt udtryk i den tyske drift og administration af lejrene i de to lande. Norge var som nævnt et tysk Reichskommisariat.

Den 15. september 1944, altså blot en måned efter lejren var taget $\mathrm{i}$ anvendelse, brød tyskerne selve grundlaget for Frøslevlejrens oprettelse ved at deportere knapt 200 fanger til kz-lejr i Tyskland.

Denne første transport blev efterfulgt af flere, således at ca. 1600 Frøslev- 
fanger blev deporteret til Tyskland.

På baggrund af dette forløb, er det nærliggende at grunde lidt over besættelsesmagtens motiver for oprettelsen af Frøslevlejren. Bests motiver, handlinger og reelle indflydelse er som sædvanlig, fristes man til at sige, uudgrundelige, men Bovensiepen, og bag ham Pancke, kan sagtens have haft en helt anden dagsorden end Best. Ret beset bevægede Best sig i Frøslevspørgsmålet i udkanten af sin ressort: det var først $\mathrm{og}$ fremmest et politianliggende, og man bør hæfte sig ved, at den endelige tyske accept af tanken om at opføre Frøslevlejren blev indhentet under et møde departementschef i Justitsministeriet Eivind Larsen havde med Bovensiepen den 3. marts 1944.

Det var også Bovensiepen, der betingede sig, at lejren blev bygget nær den dansk-tyske grænse.

Bovensiepen kan altså lige fra starten have set for sig, at Frøslevlejren kunne blive en nyttig gennemgangslejr til kz-lejrene i Tyskland. Man har fra dansk side også hæftet sig mere ved Bests halve tilsagn om en tilbageførsel af allerede deporterede til Frøslevlejren end Bovensiepens fra starten ret afvisende holdning over for denne tanke.

Selv om der altså ikke skete en egentlig tilbageførsel, og selv om 1600 Frøslevfanger blev deporteret syd på, må lejren alligevel, set med danske øjne, betegnes som en, i det mindste betinget, succes: Op mod $7.000 \mathrm{blev}$ interneret i Frøslevlejren, og såfremt lejren ikke var blevet bygget, må man antage, at flertallet af dem var blevet deporteret til Tyskland. Dertil skal lægges, at anbringelsen i Frøslev som regel betød en forhalelse af deportationstidspunktet, hvilket ikke var uvæsentlig for overlevelsesmulighederne. Dødeligheden i den første transport fra Frøslev var ca. $27 \%$, mens den gene- relt faldt adskilligt, jo senere deportationen fandt sted.

\section{Terror- und Sabotageerlass, nye deportationer}

$\mathrm{M}$ en tilbage til den tyske deportationspolitik. Beslutningen om at opføre Frøslevlejren så faktisk ud til at have sat en stopper for massedeportationerne. Til gengæld arbejdede de tyske krigsretter på højtryk med deraf følgende dødsdomme og henrettelser, blandt dem 8 fuldbyrdede dødsdomme den 29. juni 1944 over den berømte Hvidsten-gruppe, netop som den københavnske Folkestrejke stod foran sin kulmination. Hitler blev bibragt den opfattelse, at de 8 henrettelser var en udløsende faktor for folkestrejken, hvilket bekræftede ham i, at dødsdomme kun skabte martyrer og dermed ny næring til modstanden. Han forbød derfor krigsretsforfølgelser af civile i alle besatte lande - de skulle i stedet likvideres på stedet eller overgives til Sicherheitsdienst. Denne politik formulerede Hitler den 30. juli i en førerordre, som blev udsendt den 18. august 1944 under betegnelsen Terror-und Sabotageerlass.

Næste officielle tyske meddelelse om en fuldbyrdet dødsdom i Danmark kom først den 11. marts 1945! Til gengæld blev deportationerne ikke bare genoptaget, men også intensiveret, begyndende altså den 15 . september 1944 i Frøslevlejren. Det næste halve år, frem til marts 1945 , blev mere end 5.000 danske deporteret til Tyskland.Ud over den nye repressaliekurs kan også det umættelige behov for arbejdskraft i Tyskland have spillet en rolle for den udvikling.

Godt halvdelen af de deporterede var modstandsfolk, altså såkaldte "politiske" fanger. De blev typisk deporteret i hold på 100-200 - fra Frøslevlejren eller fra 
Vestre Fængsel i København.

Bortset fra en transport i oktober 1944 til Sachsenhausen og en transport fra Frøslevlejren til Dachau ved München i midten af februar 1945, gik alle transporterne til koncentrationslejren Neuengamme ved Hamburg. De få kvindelige deporterede endte som regel i Ravensbrück.

Andre knap 2000 af de deporterede var politifolk, som blev taget under den tyske aktion mod det danske politi den 19 . september 1944. Via Neuengamme blev politifolkene ført til kz-lejren Buchenwald i Weimar. Aktionen mod politiet omfattede også Grænsegendarmeriet, hvis ca. 300 tjenestegørende blev interneret i Frøslevlejren. 141, eller nøjagtig halvdelen af de gendarmer, som stadig var i Frøslevlejren, blev den 5 . oktober 1944 deporteret til Neuengamme.

\section{De vanekriminelle og de asociale}

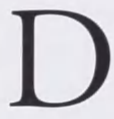
agen efter aktionen mod det danske politi, dvs. den 20. september 1944, gennemførte tyskerne en større razzia mod tilfældige civile i området omkring Axeltorv i København. De tilbageholdte blev afhørt og efter en sortering blev ca. 30 af dem den 21. - 22. september deporteret til Neuengamme sammen med et antal politibetjente fra Sjælland. Da det samlede kontingent af danske politifolk i Neuengamme blev sendt videre til Buchenwald, fulgte de ca. 30 civile med.

Hvordan deportationen af disse ca. 30 civile, ikke-politiske fanger skal tolkes, er noget uklart.

Måske var de "fyld", fordi et tal ikke stemte - altså anskuet som lovet arbejdskraft. Måske skal aktionen ses som en ren terrorhandling, eller måske var aktionen blot ouverturen til de følgende deportationer af ikke-politiske fanger fra Danmark:

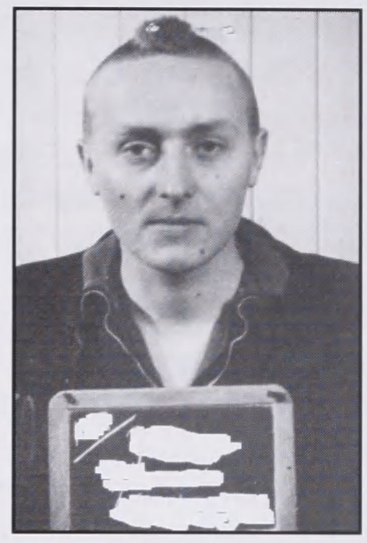

Såkaldt "asocial" fange fotograferet til det tyske fangearkiv i Froslevlejren (personlige data sloret af H.S.K.). I de tyske kz-lejre markeredes "asociale" fanger ved en sort (stof) trekant på fangedragten. I Froslevlejren blev de markeret ved en karakteristisk hanekams-klipning. Desuden blev og de såkaldt "kriminelle" fanger af kommandantskabet indsat $i$ sarlige barakker og blev udsat for darligere behandling end de almindelige "politiske" fanger, $i$ hvis fallesskab de heller ikke almindeligvis blev optaget. Foto: Froslevlejrens Museum.

Angiveligt som led i den almindelige kriminalitetsbekæmpelse efter fjernelsen af det danske politi, foranstaltede det tyske politi nemlig en mindre klapjagt på såkaldte "asociale elementer" og "vaneforbrydere". De blev uden nogen form for lov og dom indsat i henholdsvis Vestre Fængsel i København og i Frøslevlejren, og 425 af dem blev deporteret til Neuengamme i 5 transporter fra sidst i september 44 til midt i januar 45 . Det forhold at "asociale" og "vanekriminelle" var almindelige fangekategorier i de tyske kzlejre var uden tvivl befordrende for deportationerne.

Yderligere op mod 30 ikke-politiske fanger synes at være blevet transporteret til Tyskland i "politiske" transporter, f.eks. 
var der en del ikke-politiske fanger i transporten fra Frøslev til Dachau i februar 1945. Denne transport, som blev den sidste store fra Danmark, havde derved samme brogede sammensætning som de talrige transporter fra de øvrige tysk-besatte lande fra sommeren 1944.

\section{De danske myndigheders hjælp til de deporterede}

$\mathrm{F}$ ra dansk side reagerede man på den nye deportationsbølge med chok og vrede.

Direktøren i det danske Udenrigsministerium, Nils Svenningsen, afleverede efter hver deportation protestnoter til Best, og befolkningen sekunderede med omfattende strejker efter både den første deportation den 15 . september og efter politiets deportation. Aktionen mod politiet fik endda departementchefstyret til alvorligt at overveje at smide tøjlerne og gå. Men man valgte at blive og i øvrigt forstærke presset mod tyskerne for at lette forholdene for de deporterede danskere.

\section{København sad Svenningsen} som en burre på Best, afdelingsleder Frants Hvass og andre embedsmænd fra Udenrigsministeriet rendte Det tyske Sikkerhedspoliti i København på dørene, og i Berlin gjorde den danske gesandt Mohr forestillinger over for det tyske udenrigsministerium og overfor Reichsicherheitshauptamt. Siden ydede også konsulater og danske præster i Hamburg og andre tyske byer deres pression over for de enkelte kz-lejre og fængsler, og danske kolonnechefer på transport til de tyske lejre med pakkeforsendelser stod hårdnakket fast på påståede danske rettigheder over for afvisende tyske lejrkommandanter. De danske myndigheders bestræbelser, der blev udfoldet med stigende energi, som krigen led mod enden, kan sammenfattes til:
1. At lokalisere de deporterede og etablere forbindelse til de pårørende.

2. At indsamle oplysninger om og inspicere de lejre, hvor danskerne sad.

3. At formidle pakker med levnedsmidler og tøj til de deporterede, og

4. Det ultimative mål: at få hjemført de deporterede.

Det danske Socialministerium under ledelse af departementschef Koch placerede sig hurtigt i centrum for det praktiske hjælpearbejde - et arbejde, som forudsatte, og især kom til at forudsætte, medvirken af mange kræfter: Først og fremmest Udenrigsministeriet, Finansministeriet, Handelsministeriet, Varedirektoratet, Dansk Røde Kors (som entreprenør for staten og en efter Kochs mening ikke altid tilstrakkelig villig sådan!), Seruminstituttet, Sundhedsstyrelsen, tobaksindustrien og private komitéer, som forst og fremmest blev dannet af pårørende til de deporterede.

Fra de private komitéer, hvoraf den første var Stutthof Komitéen, fik myndighederne f.eks. uvurderlige oplysninger om forholdene i lejrene via korrespondancen til de pårørende. Senere, da hjemtransporterne omkring årsskiftet 1944-45 tog fart, trak Socialministeriet også på DSB og Statens Civile Luftværn, som rådede over busser og ambulancer. Og siden blev også køretøjer fra private selskaber og firmaer stillet til rådighed.

Hele dette omfattende maskineri forudsatte en central ledelse, som kunne koordinere arbejdet, og hovedkommandocentralen kom til at ligge i Socialministeriet, hvorfra også finansieringen var sikret gennem frigjorte statsmidler.

Hvis vi vender os mod myndighedernes forsendelser af pakker med levnedsmidler og tøj, lykkedes det at opnå tysk 
tilladelse til at sende pakker til alle lejre, om end formerne og hyppigheden varierede fra lejr til lejr. F.eks. kunne kommunisterne i Stutthof efter en måned modtage en månedlig pakke med levnedsmidler, hvilket snart blev øget til en pakke hver 14. dag.

Jøderne i Theresienstadt (som omfattede adskillige statsløse og tyske jøder der opholdt sig i Danmark, men som ikke desto mindre af tyskerne blev behandlet fuldstændigt som jøder med dansk statsborgerskab), derimod, kunne først fra sommeren 1944 officielt modtage pakker med levnedsmidler. Her fandt de danske myndigheder så alternative veje. Jøderne måtte nemlig godt modtage individuelle forsendelser gennem Røde Kors fra venner og pårørende. Derfor fik Socialministeriet sig manøvreret ind med penge og organisering i et tilsyneladende privat foretagende, som også omfattede den såkaldte "Ege-Kreds" og Præsternes Uofficielle Forening.

Dette betød, at jøderne fra februar 1944 regelmæssigt modtog levnedsmidler, om end altså uofficielt frem til sommeren 1944.

Det varede heller ikke længe, før de danske fanger i Sachenhausen regelmæssigt modtog pakker.

Og mht. Neuengamme - for så vidt angik selve hovedlejren - var de første 200 levnedsmiddelpakker fremme med en dansk kolonne 14 dage efter den første deportation til Neuengamme den 15 . september 1944 .

Politifolkene i Buchenwald modtog også hurtigt pakker, nemlig fra den 8 . oktober 1944, hvor den første kolonne af danske køretøjer nåede frem til lejren i Weimar.

Det normale blev, at danske fanger generelt modtog 2-3 såkaldte "Røde Kors"-pakker pr. måned.
Derimod var de mellem 800 og 1000 danske i de tyske fængsler og tugthuse mere ilde stedt, hvad angik pakker. På dette punkt var det næsten umuligt at trænge igennem for de danske myndigheder.

Først i november 1944 ser det ud til, at fængselsfangerne, der sorterede under den tyske justits og ikke SS, fik ret til at modtage pakker.

\section{$\mathrm{H}$}

De hvide Busser emtransport var, som nævnt, det ultimative mål, men på det område gik det mere trægt.

De første og, skulle det siden vise sig, såre symptomatiske erfaringer indhøstede man i forbindelse med forhandlingerne om hjemtransport af de såkaldte "fejlplacerede" jøder i Theresienstadt - dvs. "halvjøder" og heljøder, som var "arisk" gift. Jørgen Hæstrup har i sin bog om departementschefstyret, Til Landets Bedste, karakteriseret den tyske position og forhandlingsteknik på følgende måde:

"Alle danske forestillinger blev opfanget i en klæg masse af henholdende bemærkninger, løfter om undersøgelser, beklagende henvisning til manglende kompetence - alt sammen kittet sammen af almindelig, men afmægtig forståelse for de danske synspunkter".

I januar 1944 lykkedes det ikke desto mindre at fă hjemført 5 af de ca. 20 "fejlplacerede" jøder.

Først i oktober-november-december 1944 lykkedes det så småt at trænge igennem de tyske parader.

Midt i oktober erklærede Gestapochefen i Danmark, SS-Sturmbannführer Karl Heinz Hoffmann, over for Frants Hvass, at syge politifolk og politifolk med civile funktioner, som fejlagtigt var blevet 


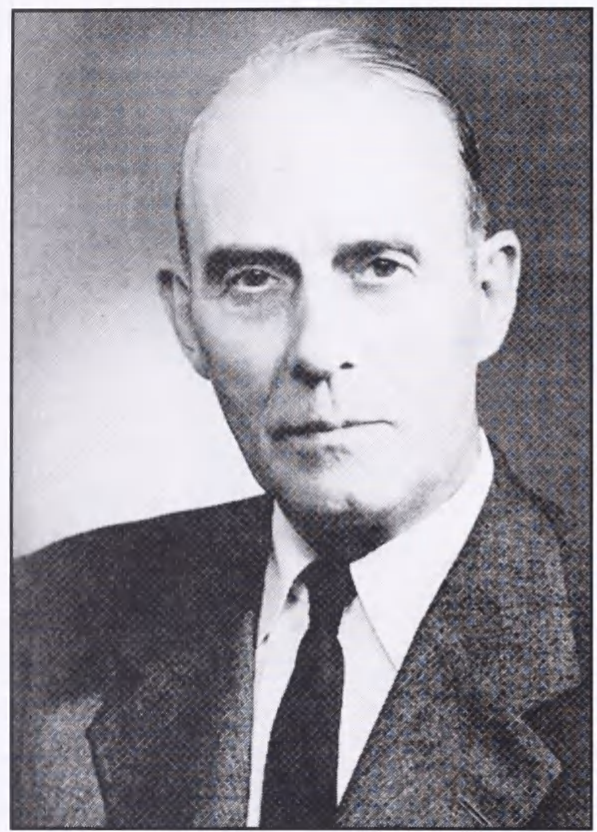

Niels Svenningsen

Noglepersoner i de danske myndigheders bestrabelser på at komme de deporterede danske til hjalp: Direktor i det danske Udenrigsministerium, Nils Svenningsen bearbejdede konstant den tyske rigsbefuldmagtigede Werner Best. Den danske gesandt i Berlin, Carl Otto Mohr, sad som en burre på Reichsicherheitshauptamt i Berlin. Og departementsschefi Socialministeriet H.H. Koch var den drivende kraft mht. forsendelserne af pakker til danske fanger $i$ Tyskland.

Fotos: Froslevlejrens Musem og Det Kongelige Bibliotek

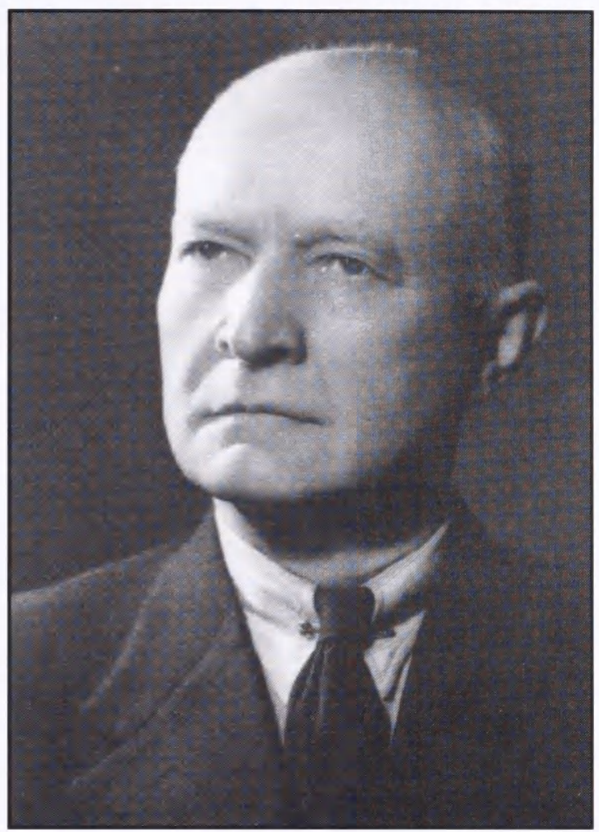

Carl Otto Mohr

\section{H.H. Koch}

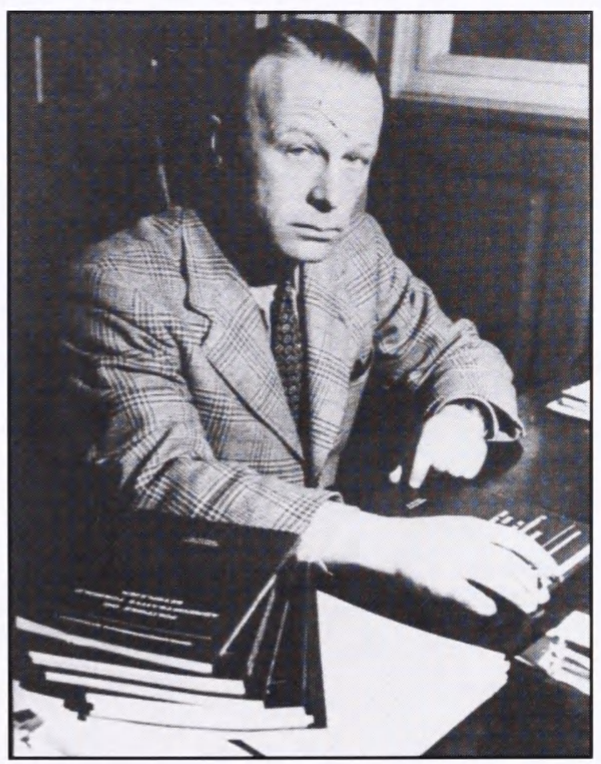


deporteret, kunne blive hjemsendt. Og et møde i begyndelsen af december 1944 mellem afdelingsleder Hvass og sikkerhedspolitichefen Bovensiepen betegnede et mindre gennembrud.

På mødet diskuterede man visse praktiske problemer i forbindelse med den forestående hjemtransport af syge politibetjente. I denne forbindelse rejste Hvass spørgsmålet om hjemtransport af andre fanger end betjentene - ud fra det sædvanlige danske argument, at deportationerne var folkeretsstridige. Dette bestred Bovensiepen og gjorde gældende, at man nu i det mindste kun deporterede danske, der stod til en dødsdom: nemlig sabotører, "politiske mordere", spioner og kommunistiske partifunktionærer. Denne udtalelse greb Hvass straks og argumenterede, at så burde personer, der $i k k e$ faldt ind under de fire kategorier, hjemføres, hvilket Bovensiepen lovede at tage under overvejelse.

Argumentet blev siden anvendt som murbrækker fra dansk side, i København såvel som i Berlin.

Tilsvarende forstod gesandt Mohr i Berlin hurtigt at udnytte en blottelse: Under en forhandling med det tyske udenrigsministerium i Berlin blev det fra tysk side fremført, at op mod $10 \%$ af de danske politibetjente havde været involveret i illegalt arbejde. Hvilket lynhurtigt førte Mohr til det modargument, at $90 \%$ af politifolkene jo så burde hjemføres!

Fra den 10. december 1944 og frem til midten af marts 1945 blev omkring 500 politifolk og grænsegendarmer samt ca. 100 såkaldt "asociale og kriminelle" fanger ført tilbage til Danmark, for de flestes vedkommende til videre internering i Frøslevlejren. Altså netop fanger, som ikke var "sabotører, politiske mordere, spioner og kommunistiske partifunktionærer".
Udviklingen skyldtes, at man fra dansk side var blevet klar over, at presset mod tyskerne måtte lægges i Berlin. Og i løbet af den første uge af marts 1945 fik Mohr og Hvass betydelige indrømmelser under to møder i Berlin med chefen for Reichsicherheitshauptamt Ernst Kaltenbrunner. Indrømmelserne vedrørte især politibetjentene.

På dette tidspunkt var hele hjemførelsesspørgsmålet trådt ind i en ny fase: Fra februar 1945 havde vicepræsidenten for Svensk Røde Kors, Grev Folke Bernadotte, ført forhandlinger i Berlin om hjemførsel af danske og norske fanger - først med Kaltenbrunner og Ribbentrop og siden den 19. februar 1945 med selveste Rigsfører Himmler, under hvem kz-lejrene sorterede.

Himmler var i første omgang negativ overfor en overførsel af fangerne til Sverige, derimod var han positiv over for, at de nordiske fanger kunne samles i et specielt afsnit i Neuengamme under Svensk Røde Kors' opsyn. Bernadotte tog herpå kontakt til den danske gesandt Mohr, og begge parter førte parallelle, selvstændige forhandlinger med Berlin. Den 12. marts 1945 nåede den første svenske kolonne Nordtyskland, men på grund af manglende erfaring arbejdede svenskerne meget langsomt. Først den 24. marts begyndte svenskerne at samle fangerne i Neuengamme, og en kompetent dansk iagttager på stedet, lægen Johannes Holm, anslog, at det ville tage svenskerne 68 uger og ikke de planlägte 10 dage at gennemføre denne operation. Da det halve af det svenske detachement omkring den 1 . april returnerede til Sverige, rykkede danskerne ind med mteriel og personel, som vlev stillet til svenskerne disposition - Bernadotte insisterede nemlig på, at han fik kommandoen over den samlede operation.

Herefter var arbejdsdelingen klar: 


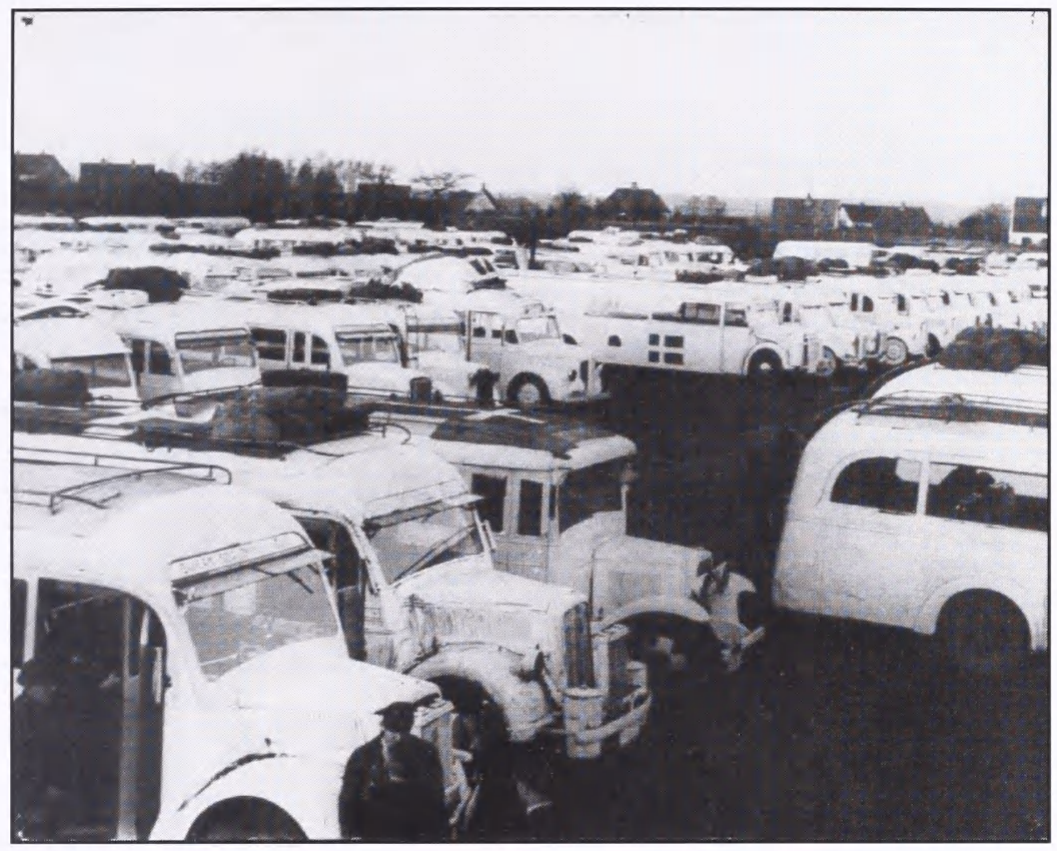

Danske Hvide Busser samlet i Padborg tet ved den dansk-tyske granse, umiddelbart forud for den store evakuering af skandinaviske kz-fanger fra kz-lejren Neuengamme den 20.-21. april 1945. Her var de skandinaviske fanger ved den svenske grev Bernadottes mellemkomst i lobet af marts 1945 blevet samlet i et specielt afsnit af lejren, som var under Svensk Rode Kors' overhojhed. Hjemtransporten blev stort set et dansk anliggende, hvori deltog en armada af $i$ hast hvidmalede busser fra DSB, Civilbeskyttelsens Udrykningskolonne samt private vognmand etc. Også chaufforer og ovrigt mandskab var dansk.

Foto: Froslevlejrens Museum

de svenske konvojer opererede fortrinsvis mellem de tyske lejre og Neuengamme, hvor fangerne blev samlet, mens transporten nordpå samt al forplejning og karantænebehandling påhvilede den danske side.

Den 2. april 1945 fik Bernadotte Himmlers tilladelse til, at alle kvindelige fanger samt en del norske studenter måtte føres fra Neuengamme til Sverige. Og også de resterende ca. 1500 danske politibetjente, som nu var bragt til Neuengamme, kunne føres nord på.

Kort efter gav Gauleiter Kauffmann i Hamburg ordre om, at alle skandina- viske fanger straks skulle føres nord på, så den 20. og 21. april 1945 hjemførte en veritabel armada af danske Hvide Busser de sidste 4.255 nordiske fanger fra Neuengamme. Fangerne blev i første omgang anbragt dels i Frøslevlejren, dels i den nyoprettede Møgelkær-lejr ved Horsens.

Den 15. april 1945 var de ca. 400 danske jøder i Theresienstadt, som ikke var omfattet af aftalen om at samle de nordiske fanger i Neuengamme, også blevet afhentet og kørt til Sverige, så med undtagelse af kommunisterne i Stutthof, der var blevet afsnøret af den russiske fremrykning, var 
stort set alle danske fanger evakueret den 21 . april 1945.

\section{De danske fangers dødelighed}

$\mathrm{B}$ etydningen af de danske myndigheders hjælp kan vanskeligt overvurderes. For at kunne forstå det, må man gøre sig klart, at tilværelsen i en kz-lejr dagligt var en nådesløs kamp for overlevelse. Her herskede jungleloven. Kampen bestod først og fremmest i at fă del i den knappe mad, og derfor var levnedsmiddelpakkerne livsreddende. Også fordi de danske fanger ved hjælp af pakkeindholdet kunne tiltuske sig fordele og begunstigelser hos både SS og overfanger, som udgjorde dronerne i det bizarre lejrhierarki. Pakkerne gjorde generelt de danske fanger til kz-lejrenes overklasse ombejlede, stærkt misundte - og ikke så sjældent forhadte!

Når de ca. 150 kommunister i

Stutthof over en deportationstid på ca. 16 måneder "kun" havde 6 dødsfald i selve lejren, kan det tilskrives pakkeforsendelserne. Men da kommunisterne i januar 1945 under Stutthofs evakuering blev jaget ud på en frygtelige dødsmarch fra øst mod vest, døde ni.

Og syv døde efter befrielsen på grund af sygdomme, de havde pådraget sig, hovedsageligt under evakueringen. Under marchen var man, hvor bizart det end må lyde, uden for den relativt trygge lejrverden, uden for de danske myndigheders rækkevidde.

\section{Det var udelukkende på grund} af den storstilede dansk-svenske evakuering, at andre danske fanger i Tyskland undgik en lignende skæbne. Det vækker til eftertanke, at ca. 7.000 Neuengamme-fanger omkom i Lübecker bugten den 3. maj 1945, da de i forbindelse med evakueringen af Neuengamme var blevet stuvet sammen i tre tyske transportskibe, som blev sænket af britiske jagerbombere.

De danske fanger i Sachsen-

hausen havde også en usædvanlig lav dødelighed ved en forholdsvis lang deportationstid: Af de i alt ca. 250 danske fanger i lejren døde 11 , svarende til ca. $4 \%$.

Pakkerne spillede en stor rolle for den lave dødelighed, men derudover var Sachsenhausen en forholdsvis "mild" lejr.

De danske jøders dødelighed i Theresienstadt var ca. 11\% over en deportationstid på 18 måneder.

Især i betragtning af alderssammensætningen (høj gennemsnitsalder) var det en lav dødelighed.

For jødernes vedkommende var det dog især en anden omstændighed, der greb ind - en omstændighed som også entydigt kan henføres til den specielle besættelsespolitiske situation i Danmark, nemlig den aftale, som blev indgået i København den 2. november 1943 mellem Werner Best og Adolf Eichmann om, at de danske jøder skulle forblive i Theresienstadt og ikke sendes videre til tilintetgørelsen i Auschwitz. Best havde ganske vist selv fremkaldt aktionen mod de danske jøder, og han var uden nogen tvivl principielt enig i den principielle, nazistiske jøde-udryddelsespolitik, men for Best var det afgørende, at de danske jøders skæbne ikke skulle blive så hård, at det ville torpedere hans bestræbelser på at etablere et godt samarbejde med de danske myndigheder, for hvem de danske jøders skæbne var et kardinalpunkt.

For de ca. 2.000 danske politifolk blev det, ud over pakkerne, livsreddende, at de danske myndigheder fik kæmpet krigsfangestatus igennem for dem. Dette betød, at de ved juletid 1944 blev overført til krigsfangelejre under Værnemagten, og trods alt meget bedre forhold end i kon- 


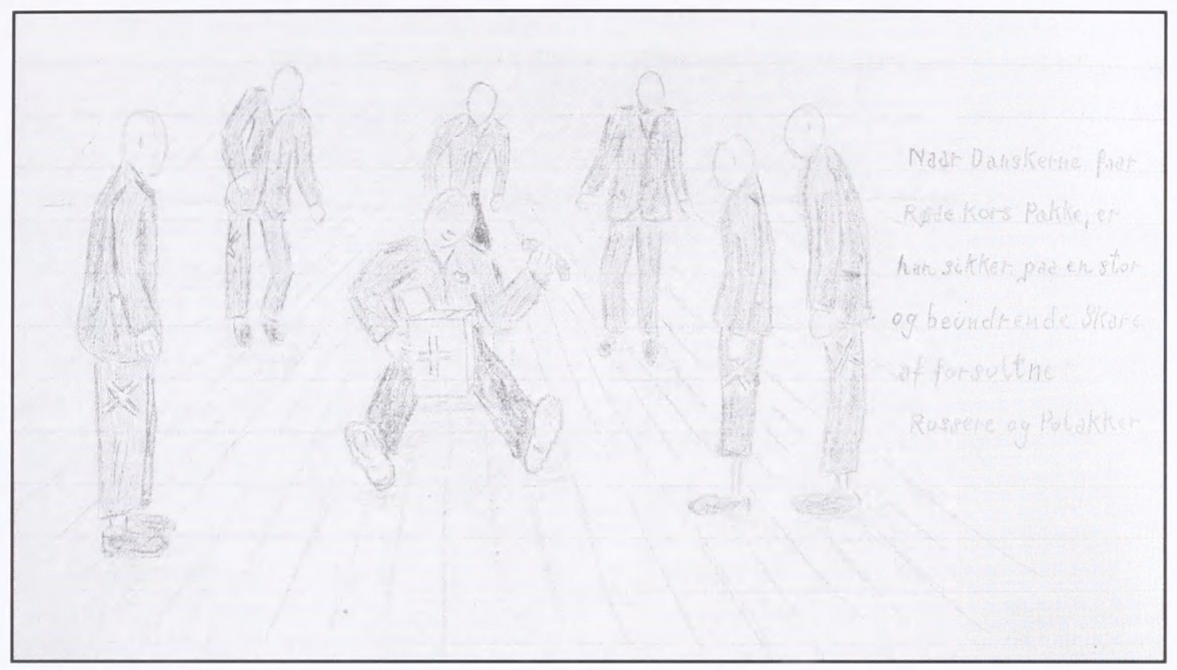

Tegning udfort af kz-fangen Jens Martin Sorensen, som fastholder de danske fangers - i sammenligning med andre nationaliteter - privilegerede forsyningssituation, samt den psykosociale reaktion denne ofte fremkaldte blandt de ovrige fanger. Froslevlejrens Museum

centrationslejren Buchenwald. Politifolkene havde en dødelighed på ca. 4\% ved en deportationstid på mellem 3 og 6 måneder.

Grænsegendarmerne, der som fremgået, var omfattet af den selvsamme tyske aktion mod politiet den 19. september 1944, havde derimod en meget høj dødelighed, nemlig ca. $27 \%$.

Selv om de danske myndigheder udfoldede store anstrengelser for også at skaffe grænsegendarmerne status som krigsfanger, lykkedes det af uransagelige årsager aldrig. Det blev skæbnesvangert for gendarmerne, at de forblev i Neuengamme og to af lejrens udekommandoer, inden de blev evakueret af de danske myndigheder i marts 1945.

Neuengamme og dens op mod 80 udekommandoer i det nordtyske område bød i det hele taget på meget barske forhold fra sommeren 1944. Ikke blot gendarmerne led høje tab. Den første transport af politiske fanger fra Frøslevlejren den 15. september 1944 havde, som tidligere nævnt, også en dødelighed på ca. $27 \%$. Fangerne i transporten endte i de berygtede udekommandoer Porta og Husum. En anden berygtet udekommando - Versen i Emsland - var stærkt medvirkende til, at en transport af politiske fanger fra Frøslevlejren den 20. oktober 1944 oplevede en dødelighed på næsten $27 \%$ ved en deportationstid på under et halvt år!

De såkaldte "asociale og vanekriminelle" fanger, som også endte i Neuengamme og berygtede udekommandoer som f.eks. Porta og Versen - havde som gruppe betragtet den højeste dødelighed: ca. 30\% ved en deportationstid på fra 3 til 7 måneder. Men altså ikke en dødelighed som var dramatisk højere end sammenlignelige "politiske" fanger!

Den høje danske dødelighed i visse af Neuengammes udekommandoer 
skyldtes dels arbejdets karakter, dels, måske, at de danske fanger her kom til geografiske afkroge, hvor pakkerne ikke nåede så hurtigt og regelmæssigt frem - og hvor lejrkommandanten ofte var en luset Scharführer, som enten ikke kendte til danske privilegier, eller også gav Fanden i dem.

\section{Hollandske og norske fangers dødelig- hed, en sammenligning}

$\mathrm{D}$ en samlede dødelighed blandt danske deporterede var ca. 10\%, svarende til ca. 600 personer.

Til sammenligning var den hollandske dødelighed $60 \%$ svarende til ca. 30.000 mennesker, og det vel at mærke uden at de hollandske jøder regnes med. Gøres det, stiger dødsraten til over $80 \%$.

Af ca. 110.000 deporterede jøder fra Holland, døde de 105.000.

Det er også nærliggende at sammenligne med nordmændene: de var som "arier" racemæssigt ligestillet med danskerne og hollænderne, og hvad angår besættelsespolitisk status var nordmændene ligestillede med hollænderne, idet både Holland og Norge var tyske Reichskommisariater. Man kunne derfor forvente en lige så høj norsk dødelighed i kz-lejrene som den hollandske. Ikke desto mindre var den "kun" ca. 15.5\%: Af ca. 9.000 deporterede nordmænd, inklusive de norske jøder, døde ca. 1.400.

De norske tal kræver imidlertid et par forklaringer. For det første modtog de norske fanger fra foråret 1943 generelt private pakker fra pårørende og fra nationale og internationale humanitære organisationer. Også de danske myndigheder formidlede i et vist omfang "Røde Kors" pakker til norske fanger. Tilsyneladende modtog de norske fanger dog ikke pakker så regelmæssigt som de danske fanger, til gengæld var de norske fanger, som fremgået, også omfattet af den dansk-svenske evakuering - en aktion, som, især i sin oprindelse, havde et kraftigt norsk islæt, uden at det skal udredes nærmere her. For det andet, sad en meget stor del af de norske fanger, ca. 2.700, i Sachsenhausen, der, som tidligere nævnt, var en forholdsvis "mild" lejr (om end udtrykket "mildhed" kan forekomme malplaceret i kz-sammenhæng). Omkring 250 af nordmændene i Sachsenhausen døde. For det tredje havde godt 1.100 af de norske fanger status som krigsfanger, og derfor nød de under hele opholdet krigsfange-konventionsrettigheder. Også de ca. 650 norske studenter, som ved årsskiftet 1943-44 blev deporteret til Sennheim og Buchenwald, nød specielle privilegier i forhold til almindelige kzfanger.

Og endelig en faktor, som ikke må undervurderes: Deportationer fra Norge i større omfang blev indstillet, efter at det tyske fangetransportskib "Westphalen" løb på en mine og sank ud for den svenske kyst $\mathrm{i}$ september 1944. I stedet blev fængsler og lejre hjemme i Norge overfyldte i krigens sidste 8 måneder (fra 1940-45 ca. 150.000 fanger i omkring 500 lejre, hvoraf mange var slaviske tvangsarbejdere og russiske krigsfanger med ekstrem høj dødelighed). Sammenligner man med danske forhold, finder man netop den store dødelighed $\mathrm{i}$ transporterne fra og med september 44 - transporter som stort set alle gik til Neuengamme. At der aldrig kom særlig mange nordmænd til Neuengamme, bortset fra under evakueringen af de nordiske fanger i foråret 1945 , skyldes måske netop deportationsstoppet $\mathrm{i}$ september 1944 som følge af skibsforliset en pointe, som tilsyneladende ikke har interesseret den temmelig sparsomme norske forskning på området.

To kategorier af norske fanger havde imidlertid en dødelighed som var 
uhyggelig typisk i europæisk sammenhæng: Af de ca. 500 Nacht und Nebel-fanger i koncentrationslejren Natzweiler døde halvdelen, og af de ca. 770 norske jøder, der blev deporteret i november $1942 \mathrm{og}$ februar 1943, blev de 735 planmæssigt ombragt i Auschwitz. I disse to fangegruppers skæbne ser man ret forskellen på norske og danske tilstande.

Fra levnedsmiddelpakken til den danske kommunist i Stutthof, - fra aftalen mellem Werner Best og

Artiklen bygger primært på:

Jørgen Hæstrup: Til landets bedste. Hovedtrek af departementschefsstyrets virke 1943-45.1971.

Henrik Skov Kristensen: En station på vej til Helvede. Harreslev banegard og deportationen af danske fanger til tyske koncentrationslejre. 2002.

Sekundært på:

Jørgen H. Barfod: Redning fra ragnarok. 1983.

Kristian Ottesen: Nordmenn i fangenskap 19401945. 1995 (1.udg.) 2004 (2.udg.).

Hans Sode-Madsen: I Hitler-Tysklands skygge. Dramaet om de danske joder 1933-1945. 2003.

Jon Reitan: " Hitlers fangeleirer - et skandinavisk sideblikk" i Heimen nr. 4 2002, s. 261278.

Samt diverse hollandske hjemmesider.
Eichmann om, at de danske jøder ikke skulle tilintetgøres,

- fra Frøslevlejrens relative fordragelighed og Den danske Forvaltnings nærende kost - og fra De hvide Busser, som reddede de danske fanger ud af Ragnarok, går der en lige linie til den i europæisk sammenhæng helt særprægede besættelsespolitiske situation i Danmark, og dermed nok så tankevækkende, dybest set til den danske kapitulation (hvad der naturligvis ikke var tale om i formel forstand) den 9. april 1940.
Artiklen er stort set identisk med en forelæsning Henrik Skov Kristensen holdt på seminaret Sonderfall Dänemark på Det Kongelige Bibliotek den 3. maj 2003. 